\title{
The Effect of Wet Cupping Therapy on High Density Lipoprotein (Hdl) and Interleukin-6 (Il-6) in Hypercolesterol Patients
}

\author{
Wahyudi Widada ${ }^{1}$, Retno Anggraini ${ }^{2}$ \\ Universitas Muhammadiyah Jember, Jawa Timur, Indonesia ${ }^{1}$ \\ Universitas Islam Sultan Agung, Semarang, Jawa Tengah, Indonesia ${ }^{2}$ \\ \{wahyudiwidada@unmuhjember.ac.id ${ }^{1}$,retno.a@unissula.ac.id² ${ }^{2}$,
}

\begin{abstract}
The aim of the study is to find out the effect of the wet cupping therapy on HDL and IL-6 in hypercholesterolemia patients. Method: This study was an experimental Quasy study using humans as research subjects. Cupping is done on 7 points. The sample size of 34 patients. Measurement of HDL dan IL6 using the sandwich ELISA method. Data analysis was performed with the Wilcoxon SR Test with a significance level of $5 \%(\alpha=0.05)$, the data pretest compared with the posttest data. Results: HDL cholesterol value pretest $34,84 \pm$ 5,20 posttest $37,57 \pm 3,25$ with $\mathrm{p}$ value 0.002 . IL- 6 value pretest $218,00 \pm$ 152,48 posttest $289,00 \pm 260,00$ with $\mathrm{p}$ value 0.018 . Conclusion: The wet cupping therapy has a significant effect on increasing the median value of HDL and IL-6. The inflammatory pathway hasn't clear yet but has been shown to increase HDL and IL-6 cholesterol.
\end{abstract}

Keywords: HDL, LDL, Cholesterol, Blood

\section{Introduction}

Hypercholesterol is a high cholesterol level in the blood. Patients must take anticholesterol drug for a long time so that the risk of experiencing side effects from the drug. High density lipoprotein (HDL) is indicator of cholesterol levels in the blood and Interleukin-6 (IL-6) is marker for inflammation. The wet cupping therapy is a method of reducing metabolic waste in the blood through inflammation pathway. The aim of the study is to find out the effect of the wet cupping therapy on HDL and IL-6 in hypercholesterolemia patients.

Treatment of hypercholesterolemia is still relying on anti-cholesterol drugs for a long time and continuously. Common side effects include liver damage and muscle disorders. One of the causes of failed treatment is the low level of compliance of patients with anti-cholesterol medications[15]. It is hoped that there are alternative medical solutions that can reduce the side effects of the drug due to its long usage. According to Mahmoud HS [9], cupping is a minor excretory surgical procedure that has a medical and scientific basis in cleaning the blood and interstitial spaces of the Causative Pathological Substances (CPS) cholesterol as the production of metabolic waste. Cupping therapy, which includes vacuumization, injury and blood suction through the skin, is thought to be able to reduce LDL cholesterol through an 
inflammatory mechanism. Keratinocytes in the skin will experience hypoxia and induce Hypoxic Inducible Factor (HIF-1 $\alpha$ ) as an effort to self-defense[19]. HIF-1 $\alpha$ will activate macrophages in the skin which in turn induce pro-inflammatory genes such as Interleukin-1 (IL-1). IL-4, IL-6 and Tumor Necrosis Factor- $\alpha$ (TNF- $\alpha$ ). Interleukin- 6 secreted by macrophages plays a role in stimulating the body's immune response, for example after trauma or tissue damage that leads to inflammation[5]. The release of IL-6 stimulates young macrophage cells to mature and be able to carry out phagocytosis more efficiently[8]. The acceleration of macrophage migration also increases due to IL-6 stimulation [7]. IL-6 also stimulates monocytes produce inflammatory cytokines that play a role in local and systemic inflammation, as a result accelerated proliferation and differentiation of macrophages [21].

HDL cholesterol functions as an absorber of LDL cholesterol from macrophages and peripheral tissues with the help of pre $\beta$-HDL and the enzyme Lecithin Cholesterol Asyl Transferase (LCAT). Pre $\beta$-HDL has a role in the reverse cholesterol transport process which can increase cholesterol efflux to be carried to the liver and excreted as bile [12]. The increased cholesterol efflux causes the Apo-B levels to rise. Apo-B is essential for binding of LDL particles to LDL receptors, which allows cells to internalize LDL and then absorb it.[17]. This study aims to determine the effect of wet cupping therapy on HDL and IL-6 in hypercholesterolemic patients. This research was conducted on humans. The results obtained will be useful in the development of complementary therapies in hypercholesterolemic sufferers.

\section{Method}

This study was an experimental Quasy study using humans as research subjects. The dependent variable HDL and IL-6 were treated with cupping wet therapy hijamah. Cupping is done twice, 7 points, using a G21 needle. The sample size of 34 people with hypercholesterol patients was divided into treatment group and control group. The research subjects were selected based on sample inclusion criteria. After 12 hours of fasting and still taking simvastatin, blood was taken through a $5 \mathrm{ml}$ brachial vein. Inserted into a $2 \mathrm{ml}$ purple tube containing the remaining EDTA, a red tube is inserted. Measurement of HDL dan IL-6 using the sandwich elisa method, elabscience reagent, Biopham reader, in units of $\mathrm{mg} / \mathrm{ml}$. Total cholesterol uses the enzymatic colourimetry method, diasys reagent, Biolyzer100 spectrophotometric device, in units of $\mathrm{mg} / \mathrm{dl}$. Data analysis was performed with the Wilcoxon Signed Ranks Test with a significance level of $5 \%(\alpha=0.05)$, the data pretest compared with the posttest data.

\section{Results}

HDL cholesterol value pretest $34.49 \pm 5.20$, Posttest $37.64 \pm 3.25$ with $\mathrm{p}$ value 0.002 . IL-6 value pretest $218.00 \pm 152.48$. Posttest $289 \pm 260$ with $p$ value 0.018 . 
Table 1. Analysis Results

\begin{tabular}{ccccc}
\multicolumn{5}{c}{ Table 1. Analysis Results } \\
\hline \multirow{3}{*}{ Group } & \multirow{2}{*}{$\mathbf{n}$} & \multicolumn{2}{c}{$\begin{array}{c}\text { Pre-post test } \\
\text { Median } \pm \text { SD }\end{array}$} & \multirow{2}{*}{ p } \\
\cline { 3 - 4 } & & Pretest & Posttest & \\
\hline HDL & 17 & $34.84 \pm 5.20$ & $37.57 \pm 3.25$ & 0.002 \\
Il-6 & 17 & $218.00 \pm 152.48$ & $289.00 \pm 260$ & 0.018 \\
\hline
\end{tabular}

In the HDL group $(p=0.002)$ it was significant, meaning that there was a difference in the mean HDL between the pretest and posttest groups. In the IL- 6 group $(p=0.018)$ it was significant, meaning that there was a difference in the mean IL-6 between the pretest and posttest groups.

So the treatment in the HDL group had the effect of increasing the mean HDL value significantly. This is beneficial because HDL functions to reduce high LDL cholesterol levels in the blood. Cholesterol is carried to the liver to be excreted in the form of bile salts.

Treatment of wet cupping therapy had the effect of increasing the mean IL-6 value significantly. This is beneficial because IL-6 functions to increase inflammatory reactions that are useful to reduce high LDL cholesterol levels in the blood.

Lipids absorbed from food and lipids synthesized by the liver from adipose tissue must be transported to various tissues and organs for use and storage. Plasma lipids consist of TG (16\%), phospholipids $(30 \%)$, cholesterol $(14 \%)$, cholesterol esters $(36 \%)$, and free fatty acids (4\%). Lipids are transported in plasma as lipoproteins[18]. There are four main groups of lipoproteins, namely chylomicrons, Very Low Density Lipoproteins (VLDL), Low Density Lipoproteins (LDL), and High Density Lipoproteins (HDL). Chylomicrons transport lipids that result from digestion and absorption; VLDL transports TG from the liver; LDL carries cholesterol to tissues; and HDL carries cholesterol from the tissues and returns it to the liver for excretion in a process known as reverse cholesterol transport.[16].

After taking free cholesterol from macrophage cells, free cholesterol will be esterified into cholesterol esters by the enzyme Lechitin Cholesterol Acyl Transferase (LCAT). Furthermore, some of the cholesterol ester carried by HDL will take two paths. The first route is to the liver and is captured by the class B type 1 scavenger receptor known as SR-B1. The second line is that the cholesterol ester in HDL will be exchanged with TG from VLDL and IDL with the help of Cholesterol Ester Transfer Protein (CETP)[6]. Cholesterol esters move to the center of particles and gradient for movement of cholesterol esters from cell membranes to pre $\beta$-HDL particles [20].

HDL particles which are known to work as anti-inflammatory and antioxidants have been considered to have a suppressive role in controlling monocyte activation as well as the proliferation and differentiation of monocyte progenitor cells [10]. The main function of HDL is to transport cholesterol back and efflux from cholesterol, and its role in the inflammatory process[11]. It has been shown that HDL cholesterol has anti-inflammatory, antioxidant and anti-thrombotic effects. HDL, which is known as an anti-atherogenic lipoprotein, causes the transport of cholesterol back from the artery walls, especially from the body of macrophages.[3]. HDL is very effective in inhibiting adhesion of molecules in the endothelium and preventing the arrival of monocytes to the arterial walls. HDL can inhibit the inflammatory response by acting directly on the monocytes themselves [4].

Wet cupping therapy increases the amount of HDL while HDL acts as a carrier for LDL cholesterol. HDL with the help of the ABC-1 enzyme increases the efflux of LDL cholesterol from tissues and macrophages. The greater the amount of HDL, the more LDL cholesterol HDL transports to the liver [3]. Cholesterol which is carried to the liver is then excreted into 
bile salts. Finally, the LDL cholesterol level in the serum decreases. Researchers assume HDL and macrophages are the key to the success of this mechanism. HDL plays a role in reducing the amount of LDL cholesterol in the plasma and preventing the occurrence of LDL-ox[18].

IL-6 particles have various functions against the target so that they are considered as the main mediator of inflammation and the immune system. IL- 6 is bound to IL-1 and TNF because these three cytokines are produced by monocytes / macrophages. This attachment is also due to their respective functions to induce the release of other types of monokines. These three cytokines can be transported by the bloodstream to generate an inflammatory reaction called the acute immune response [14].

These results are consistent with research [16]who reported IL-6 to be anti-inflammatory. Research[17]also reported decreased IL-6 in both the treatment and control groups. But few journals report that IL-6 is decreased in the inflammatory pathway. Several journals suggest that IL-6 is reported to be increased as part of an inflammatory pathway. Interleukin-6 (IL-6) will further stimulate inflammation. In IL-6, which is secreted by T cells and macrophages, its role is to stimulate an immune response, for example after trauma or tissue damage has occurred that leads to inflammation.[8]. The release of IL-6 stimulates young macrophage cells to mature and mature macrophage cells will be able to perform phagocytosis more efficiently[1]. Increased levels of IL-6 are associated with the highest risk for cardiovascular disease. IL-6 is to increase the differentiation of monocytes into macrophages. IL-6 is linked in. decreased cholesterol[15] associated with reduced non-HDL cholesterol. Cupping therapy is an injury and trauma. Local reactions at the site of injury or infection lead to cytokine activation which triggers a systemic response consisting of leukocytosis[21].

\section{Conclusion}

The wet cupping therapy has a significant effect on increasing HDL. The inflammatory pathway is unclear but has been shown to increase HDL cholesterol. The inflammatory pathway hasn't clear yet but has been shown to increase HDL and IL-6 cholesterol.

\section{Acknowledgement}

Our thanks go to Muhammadiyah University of Jember and Universitas Islam Sultan Agung, Indonesia.

\section{References}

[1] Angellica Rossi Sartori-Cintra.Regulation of hypoxia-inducible factor-1a (HIF-1a) expression by interleukin-1b (IL-1b), insulin-like growth factors I (IGF-I) and II (IGFII) in human osteoarthritic chondrocytes CLINICS 2012;67(1):35-40.(2012)

[2] Besung dkk. Hubungan Antara Aktivasi Makrofag Dengan Kadar Interleukin-6 Dan Antibodi Terhadap Salmonella typhi Pada Mencit. Fakultas Kedokteran Hewan Universitas Udayana, Denpasar. (2016)

[3] Ghattas, A., GriffithsHR, A, D., GY, L., \& E., S. Monocytes in coronary artery disease and atherosclerosis: where are we now? J Am Coll Cardiol, 62(17), 1541-1551. https://doi.org/10.1016/j.jacc.2013.07.043 (2013)

[4] Karabacak M, Kahraman F, Sert M, et al. Increased plasma monocyte chemo attractant protein-1 levels in patients with isolated low high density lipoprotein cholesterol. 
Scand J Clin Lab Invest 2015;75(4):327-32 (2015)

[5] Kelly, A., Gunaltay, S., McEntee, C. P., Shuttleworth, E. E., Smedley, C., Houston, S. A., Fenton, T. M., Levison, S., Mann, E. R., \& Travis, M. A. Human monocytes and macrophages regulate immune tolerance via integrin $\alpha \mathrm{v} \beta 8$-mediated TGF $\beta$ activation. Journal of Experimental Medicine. https://doi.org/10.1084/jem.20171491(2018)

[6] Kwiterovich, P.O. The metabolic pathways of high-density lipoprotein, low-density lipoprotein, and triglycerides: a current review. The American Journal of Cardiology. https://doi.org/10.1016/S0002-9149(00)01461-2 (2000).

[7] Lee, J. S., Chang, P. Y., Zhang, Y., Kizer, J. R., Best, L. G., \& Howard, B. V. Triglyceride and HDL-C dyslipidemia and risks of coronary heart disease and ischemic stroke by glycemic dysregulation status: The strong heart study. Diabetes Care. https://doi.org/10.2337/dc16-1958 (2017)

[8] Lubrano, Gabriele, Puntoni, Longo, \& Pucci. Relationship among IL-6, LDL cholesterol and lipid peroxidation. Cell Mol Biol Lett., Jun;20(2), 310-22. (2015)

[9] Mahmoud, H. S., Abou-El-Naga, M., Omar, N. A. A., El-Ghazzawy, H. A., Fathy, Y. M., Nabo, M. M. H., \& Sayed, S. M. El. Anatomical Sites for Practicing Wet Cupping Therapy (Al-Hijamah): In Light of Modern Medicine and Prophetic Medicine. Ahem Integ Med, 2: 138, 2-30. https://doi.org/10.4172/2327-5162.1080138, (2013)

[10] Mahmoud HS, E. S. S. Medical and Scientific Bases of Wet Cupping Therapy (Alhijamah): in Light of Modern Medicine and Prophetic Medicine. Alternative \& Integrative Medicine. https://doi.org/10.4172/2327-5162.1000122 (2013)

[11] Navab, M., Reddy, S. T., Van Lenten, B. J., \& Fogelman, A.M. HDL and cardiovascular disease: Atherogenic and atheroprotective mechanisms. In Nature Reviews Cardiology. https://doi.org/10.1038/nrcardio.2010.222 (2011)

[12] Sajid, M.I. Hijama therapy (wet cupping) - its potential use to complement British healthcare in practice, understanding, evidence and regulation. Complementary Therapies in Clinical Practice. https://doi.org/10.1016/j.ctcp.2016.01.003 (2016)

[13] Sayed, S. M. El, Mahmoud, H., \& Nabo, M. Medical and Scientific Bases of Wet Cupping Therapy (Al-hijamah): in Light of Modern Medicine and Prophetic Medicine. Alternative \& Integrative Medicine. https://doi.org/10.4172/2327-5162.1000122 (2013)

[14] Subowo. Imunobiologi (3rd ed.). Sagung Seto, (2013).

[15] Takata, K., Imaizumi, S., Zhang, B., Miura, S. I., \& Saku, K. Stabilization of high-risk plaques. In Cardiovascular Diagnosis and Therapy. (2016)

[16] Trajkovska, K. T., \& Topuzovska, S. High-density lipoprotein metabolism and reverse cholesterol transport: Strategies for raising HDL cholesterol. Anatolian Journal of Cardiology. https://doi.org/10.14744/AnatolJCardiol.2017.7608 (2017)

[17] Umemoto, T., Han, C. Y., Mitra, P., Averill, M. M., Tang, C., Goodspeed, L., Omer, M., Subramanian, S., Wang, S., Den Hartigh, L. J., Wei, H., Kim, E. J., Kim, J., O'Brien, K. D., \& Chait, A. Apolipoprotein AI and high-density lipoprotein have antiinflammatory effects on adipocytes via cholesterol transporters: ATP-binding cassette A-1, ATP-binding cassette G-1, and scavenger receptor B-1. Circulation Research, 112, 1345-1354. https://doi.org/10.1161/CIRCRESAHA.111.300581(2013)

[18] Westerterp, M., Gourion-Arsiquaud, S., Murphy, A. J., Shih, A., Cremers, S., Levine, R. L., Tall, A. R., \& Yvan-Charvet, L. Regulation of hematopoietic stem and progenitor cell mobilization by cholesterol efflux pathways. Cell Stem Cell. https://doi.org/10.1016/j.stem.2012.04.024 (2012)

[19] Westra, J., Brouwer, E., Van Roosmalen, I. A. M., Doornbos-Van Der Meer, B., Van Leeuwen, M. A., Posthumus, M. D., \& Kallenberg, C. G. M. Expression and regulation 
of HIF-1alpha in macrophages under inflammatory conditions; Significant reduction of VEGF by CaMKII inhibitor. BMC Musculoskeletal Disorders. https://doi.org/10.1186/1471-2474-11-61(2010)

[20] Yan, X., Yao, M., Wen, X., Zhu, Y., Zhao, E., Qian, X., Chen, X., Lu, W., Lv, Q., Zhang, L., \& Lu, F. Elevated apolipoprotein B predicts poor postsurgery prognosis in patients with hepatocellular carcinoma. OncoTargets and Therapy. https://doi.org/10.2147/OTT.S192631 (2019)

[21] Yang, J., Zhang, L., Yu, C., Yang, X.F., \& Wang, H. Monocyte and macrophage differentiation: Circulation inflammatory monocyte as biomarker for inflammatory diseases. Biomarker Research, 2, 1. https://doi.org/10.1186/2050-7771-2-1(2014) 